\title{
Factores e indicadores de la calidad física, sensorial y química del café
}

“APLICACIÓN dE CIENCIA, TECNOLOGÍA E INNOVACIÓN EN EL CULTIVO del CAFÉ AJUSTAdO a LAS CONDICIONES PARTICULARES DEL HUILA" 



\section{Introducción}

Colombia cuenta con características agroecológicas (altitud, clima y suelo) y factores humanos que permiten la máxima expresión de las cualidades intrínsecas del café, generando los elementos necesarios para continuar con su posicionamiento en el mercado de calidad superior. Dicha calidad depende de numerosos factores, entre los cuales se destacan: la especie, la variedad cultivada, las condiciones ambientales, las prácticas agronómicas del cultivo, el método de beneficio empleado, las condiciones de almacenamiento del grano, el procesamiento industrial y la preparación de la bebida (Figura 1).

La producción de café de calidad requiere un compromiso continuo de monitoreo y seguimiento de los factores que influyen en ella, estos van desde el cultivo hasta tener el grano disponible para el análisis sensorial o la llamada prueba de taza, que es donde se manifiestan todos sus atributos o quedan en evidencia defectos que pudieron tener origen en alguna parte de las etapas, desde la producción, beneficio y almacenamiento del grano.
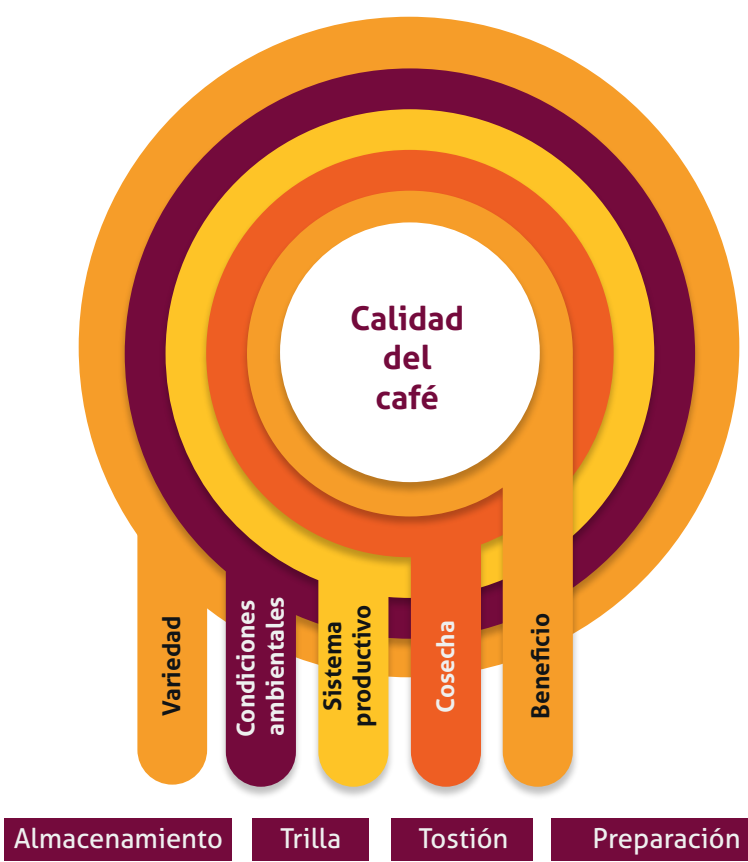

Análisis sensorial de café

Figura 1. Factores que influyen en la calidad del café. 
Desde el año 2015, la Gobernación del Huila con recursos del Sistema General de Regalías, el Comité Departamental de Cafeteros y el Centro Nacional de Investigaciones de Café - Cenicafé, generaron actividades encaminadas a apoyar la producción cafetera en la creciente demanda internacional de café de alta calidad. En este sentido se generaron estrategias para el control de la calidad del café, que impacten positivamente la comercialización, al ofrecer a los clientes finales un producto con mayor fidelidad desde el punto de vista de calidad y que, además apuntan al mejoramiento de la cultura del café, a través del monitoreo continuo a la calidad del departamento mediante el análisis físico, químico y sensorial del café. En este capítulo se abordarán diferentes temas encaminados a explicar los factores que tienen impactos en la calidad, los indicadores de los diferentes análisis de calidad y los resultados obtenidos en la caracterización del café producido en el departamento del Huila entre los años 2015 y el 2018.

\section{Influencia del beneficio en la calidad}

El fruto de café en estado de madurez se torna rojo y recibe el nombre de cereza. Estas cerezas por su alto contenido de agua son altamente perecederas, y por tal motivo deben someterse a un proceso denominado beneficio. El beneficio húmedo del café se define como el conjunto de operaciones que se realizan para transformar el café en cereza en café pergamino seco (Cenicafé, 1991). Este proceso debe conservar la calidad exigida por las normas de comercialización y evitar pérdidas del producto.

El beneficio húmedo da lugar a los cafés conocidos como lavados, cuyo proceso es el más utilizado en Colombia. Como su nombre lo indica, el beneficio involucra el uso de agua e implica la eliminación de la pulpa y el mucílago del café, así como el lavado antes del secado, solar o mecánico (Figura 2).

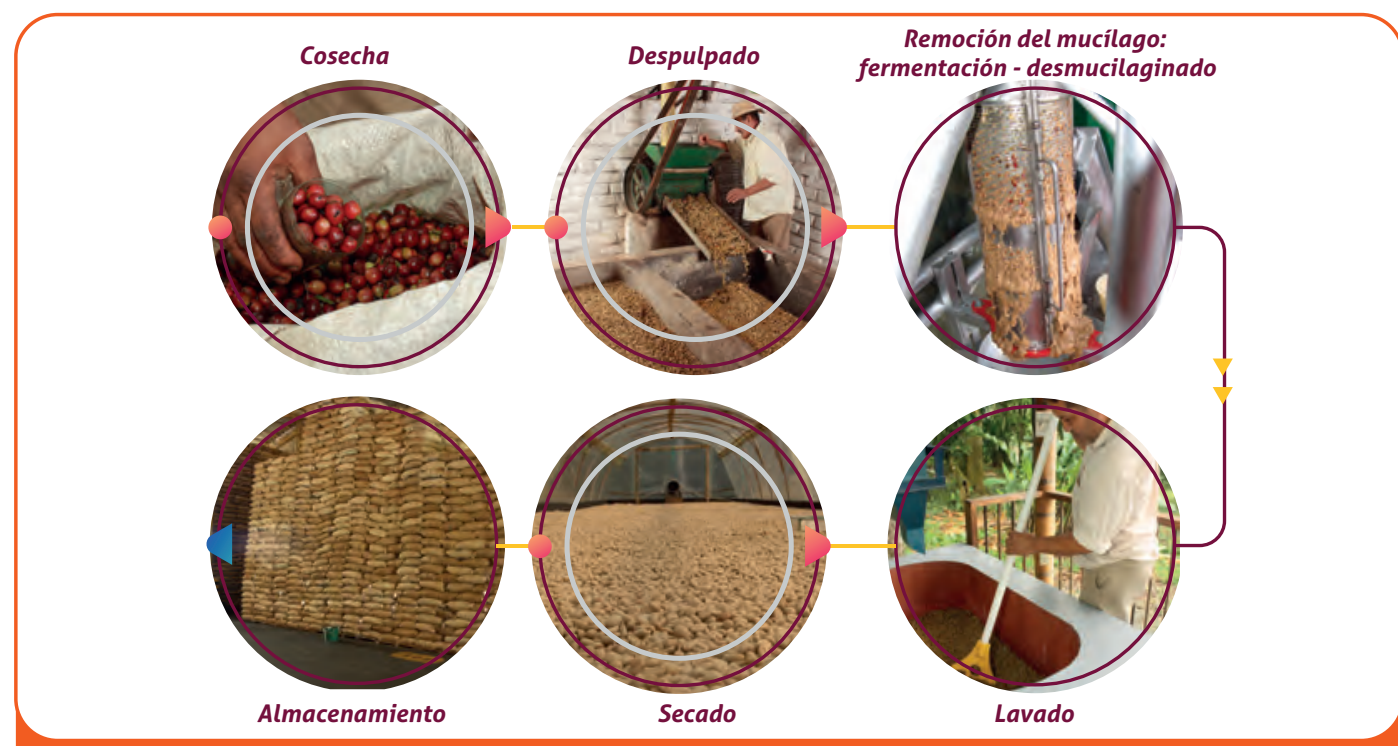

Figura 2. Operaciones realizadas en el beneficio húmedo. 


\section{Recolección}

La cosecha de los frutos se realiza habitualmente con el criterio práctico del color del fruto que presenta varias tonalidades rojizas. La recolección que se realiza en Colombia se denomina selectiva, puesto que se realiza de forma manual, seleccionando de manera oportuna frutos maduros, haciendo los pases necesarios y evitando que los frutos queden en la planta y se conviertan en hospedantes de la broca (Isaza et al., 2006).

Las variaciones en las condiciones climáticas de cada una de las zonas cafeteras colombianas afectan la uniformidad de maduración, observándose en una misma rama frutos de diferentes estados y grados de madurez (Marín et al. 2003), por este motivo, la observación constante de los lotes por parte de los caficultores durante su maduración permite planificar la cosecha del café cereza, cuando se encuentre en su estado óptimo de desarrollo.

Algunos estudios han determinado que los mejores atributos sensoriales de la bebida se obtienen de frutos maduros, mientras que los verdes y pintones pueden deteriorar la calidad debido a múltiples defectos como la astringencia, sabores a cereal y acre (Puerta, 2000). De igual manera, los frutos secos originan defectos que van desde el fermento, mohos, sabores y olores extraños. Lo anterior, indica la importancia que tiene la recolección oportuna para obtener una buena calidad física y sensorial del café.

\section{Despulpado}

Consiste en retirar la pulpa de la cereza por medio de la presión y fricción que ejerce el cilindro de la despulpadora contra el pechero y la camisa. El ajuste de estos componentes en relación con el tamaño y madurez del fruto determina la calidad del café despulpado. Esta operación debe iniciarse inmediatamente después de cosechar los frutos.

El café con un grado óptimo de maduración contiene mucílago que permite un fácil despulpado (al presionar la cereza), evitando el uso del agua en esta etapa (Roa et al., 1999). En este proceso los granos no deben sufrir algún daño ni cambio físico, es decir, deben conservar su integridad.

\section{Remoción de mucílago}

El mucílago es un hidrogel compuesto principalmente por agua, azúcares y sustancias pécticas. Este recubre o envuelve el grano despulpado, tiene de 0,4 a 2,0 mm de espesor, representando aproximadamente el $22 \%$ del peso del café despulpado. La cantidad del mucílago depende en gran medida del grado de madurez del fruto (Peñuela, 2010).

En el método de beneficio húmedo debe removerse mediante el proceso de fermentación natural o mecánica. La composición química del mucílago en combinación con las levaduras y bacterias presentes en el ambiente y en los equipos donde se realiza el beneficio húmedo, explica la ocurrencia natural de la fermentación a temperatura ambiente, sin recurrir a inoculaciones (Puerta, 2010). 


\section{Remoción del mucílago por fermentación} natural. La fermentación del mucílago de café es un proceso biológico donde las enzimas producidas por las levaduras y las bacterias descomponen los azúcares contenidos en éste, generando el rompimiento de la estructura y facilitando su eliminación completa durante la etapa de lavado; tradicionalmente, se realiza en tanques de concreto, con revestimiento de acero inoxidable (Figura 3) y plástico (Puerta, 2015).

En este proceso intervienen numerosos factores biológicos, químicos y físicos, sin embargo, se han referenciado los principales factores que pueden incidir en su duración: temperatura del ambiente, uso de agua durante el despulpado y la fermentación y el grado de madurez, asociado con la cantidad del mucílago en el grano, aunque se desconoce específicamente el efecto de estas variables sobre el tiempo de finalización de la fermentación del mucílago.

Por este motivo, anteriormente los caficultores recurrían a métodos tradicionales para determinar el punto de finalización del proceso de fermentación y de lavado del café. Los métodos más utilizados eran: el orificio y el tacto, es decir, la presencia del agujero dejado por un madero cuando es introducido en la masa de café y la sensación áspera detectada por el tacto al tomar una muestra de café y lavarla, sin embargo son mediciones subjetivas del punto de lavado, que dependen de la experiencia del usuario y aunque la prueba fuera positiva en la mayoría de los casos, el café debía lavarse varias veces para asegurar la eliminación completa del mucílago, aumentando el consumo específico de agua y poniendo en riesgo la calidad final del café (Peñuela, 2010). La falta de controles objetivos en esta etapa tiene incidencia directa en la calidad del café. Peñuela et al. (2012) demostraron que un retraso en el tiempo de fermentación, mayor a 2 horas después de que el proceso ha finalizado, tiene efecto directo en la aparición de defectos en taza tales como vinagre y fermento.

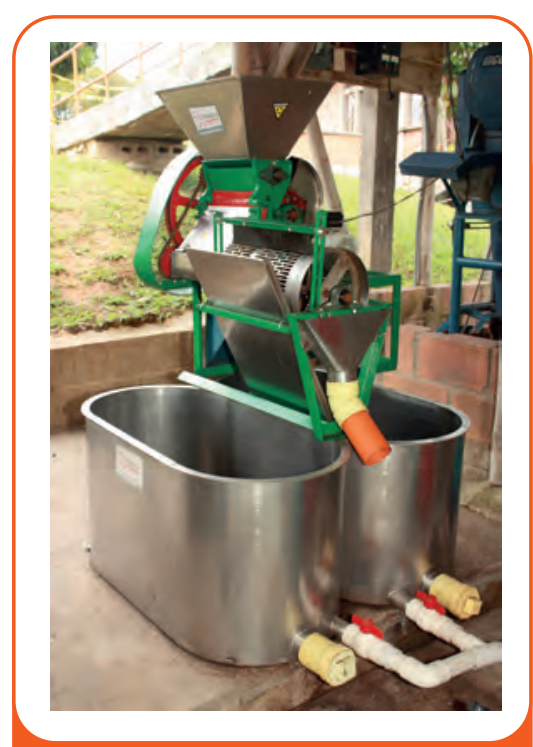

Figura 3. Tanques de fermentación.

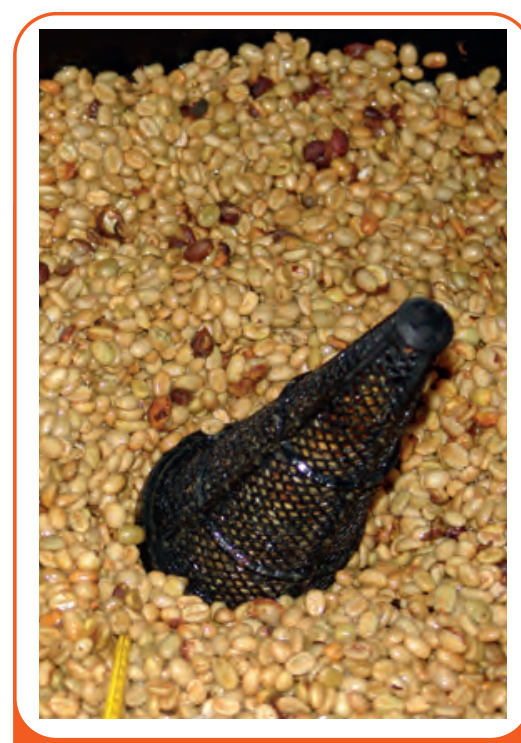

Figura 4. Dispositivo

FermaestroTM para determinar el punto final de la fermentación del mucílago del café.

En Cenicafé se desarrolló un dispositivo llamado Fermaestro ${ }^{\text {TM }}$ (Peñuela et al. 2013), para verificar el momento de la finalización del proceso de fermentación, para su posterior lavado. El Fermaestro ${ }^{\mathrm{TM}}$ es un recipiente perforado, en forma de cono truncado (Figura 4), donde se deposita una muestra de café recién despulpado y se introduce en la masa de café en proceso de fermentación y a medida que avanza el proceso, disminuye 
el volumen ocupado por la masa de café en el dispositivo, debido al cambio de densidad aparente del café y del drenado del mucílago, lo que ocasiona el aumento de la altura del espacio vacío en la parte superior del Fermaestro. Cuando se estabiliza dicha altura, significa que se ha alcanzado el punto de lavado.

\section{Desmucilaginado mecánico. El mucílago} también puede removerse por medios mecánicos a través del uso de agitadores, a altas velocidades, que promueven roces entre los granos de café recién despulpados y las partes móviles y fijas del equipo, para realizar el desprendimiento del mucílago (Figura 5). En Cenicafé, se desarrolló el Becolsub, tecnología donde se integran el despulpado, remoción de mucílago y lavado del café (Roa et al., 1999). En esta tecnología, todas las máquinas acopladas y la cantidad de agua, deben ser calibrados para garantizar el correcto funcionamiento, debido a que los granos pueden quedar con restos de mucílago que podrían continuar su proceso de fermentación durante el secado y generar defectos a la calidad del café (Pabón et al., 2009).

Lavado. El lavado permite retirar totalmente el mucílago fermentado del grano. Normalmente se realiza añadiendo agua limpia y filtrando en repetidas ocasiones al tanque de fermentación. El uso de agua limpia evita defectos físicos y sensoriales como el grano manchado y sabores a fermento.

En Cenicafé se desarrolló el tanque tina, que reduce el consumo de agua contribuyendo a las prácticas sostenibles en el proceso productivo del café. El tanque consiste en una estructura rectangular, con esquinas redondeadas, con la capacidad para que se realice el proceso de fermentación del mucílago y un eficiente lavado y clasificación del café (Zambrano, 1993). El lavado en el tanque tina (Figura 6) se consumen menos de cinco litros de agua por cada kilogramo de café pergamino seco. El lavado del café fermentado se lleva a cabo dentro del tanque tina, haciendo cuatro enjuagues, en el cuarto y último enjuague se adiciona agua hasta cinco centímetros por encima de la masa de café y se agita para retirar los flotes o granos vanos. Finalmente, se hace el último drenaje y la descarga.

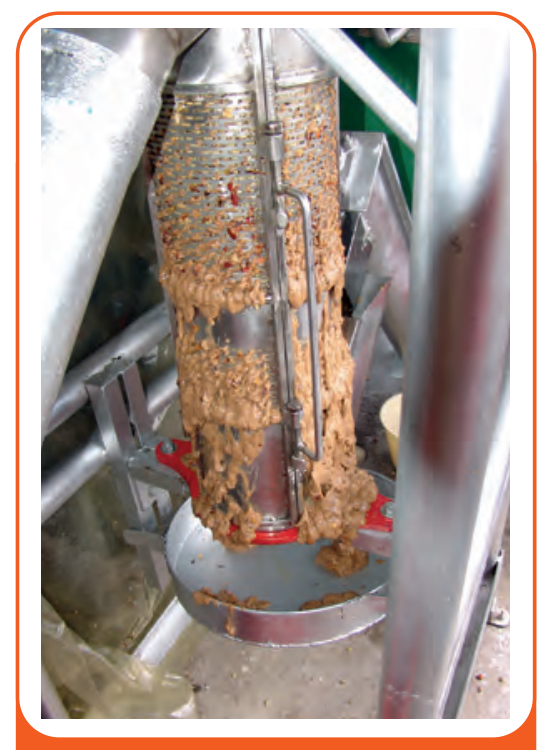

Figura 5. Desmucilaginador mecánico.

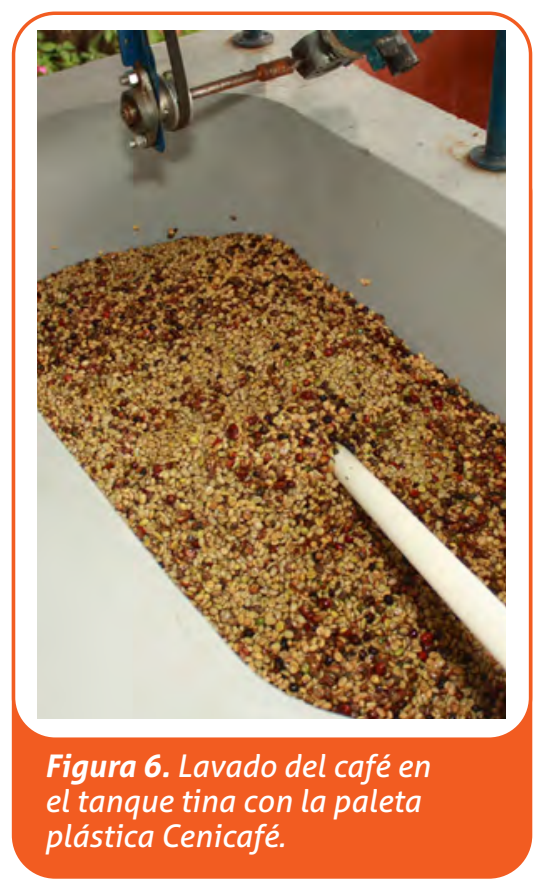


En 2013, Cenicafé lanzó la tecnología Ecomill@ (Oliveros et al., 2013), donde se emplea la fermentación natural para degradar el mucílago y el café se lava mecánicamente, con reducción notoria en el volumen específico de agua, hasta valores entre 0,3 y 0,5 L/kg de c.p.s (Figura 7).

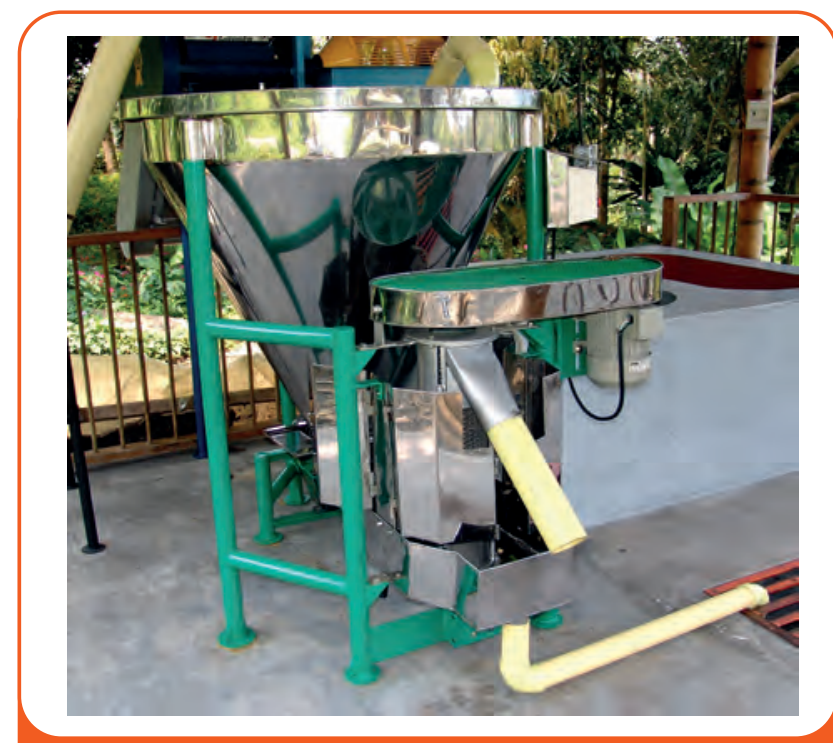

Figura 7. Tecnología Ecomill@.

Secado. El secado es un proceso de eliminación de agua que logra la conservación y la estabilidad del café durante su almacenamiento y comercialización, al disminuir el contenido y la actividad del agua en el café. El punto de equilibrio corresponde a $12 \%$ de contenido de humedad; el café con humedad mayor a 12,5\% (actividad de agua superior a 0,7) puede causar pérdidas a la calidad del grano, al producir calentamiento de la masa y generar focos de hongos e insectos (Puerta, 2006).

Los principales factores para el crecimiento de los microorganismos son el sustrato, la disponibilidad de agua, la temperatura y el pH. Los métodos de preservación de la calidad de los alimentos se basan en principios que buscan disminuir la disponibilidad de agua, reducir la temperatura, controlar el pH o variar el potencial de óxido reducción (Puerta, 2006). El proceso de secado en café disminuye el contenido inicial de agua entre 50\% - 55\% hasta el 10\% - 12\%, aproximadamente, obteniendo el denominado café pergamino seco (c.p.s).

La temperatura del aire de secado tiene influencia significativa en la calidad del grano, temperaturas excesivamente altas ocasionan defectos como los granos cristalizados. Para establecer las temperaturas máximas utilizadas durante el proceso de secado, es necesario considerar que la temperatura del aire casi siempre es mayor que la temperatura del grano y, en muchos secadores, durante la última etapa de secado, la masa de granos alcanza la temperatura del aire.

Los granos que van a ser utilizados como semillas deben conservar un alto porcentaje de germinación y las altas temperaturas dañan el embrión. Para garantizar la viabilidad de las semillas se recomienda no dejar que la temperatura del grano sobrepase los $38^{\circ} \mathrm{C}$ durante el secado. Así mismo, con el fin de asegurar una buena calidad, se recomienda no secar los granos a temperaturas superiores a los $50^{\circ} \mathrm{C}$. En Colombia el proceso de secado se efectúa de dos maneras: secado al sol y por medios mecánicos utilizando silos de capa estática principalmente. 
Secado natural o solar. El secado natural o al sol se logra al disponer los granos húmedos sobre superficies que permitan su interacción directa con la energía proveniente del sol y del aire (Figura 8). Este tipo de secado permite obtener un producto final con una humedad muy uniforme y con un bajo costo.

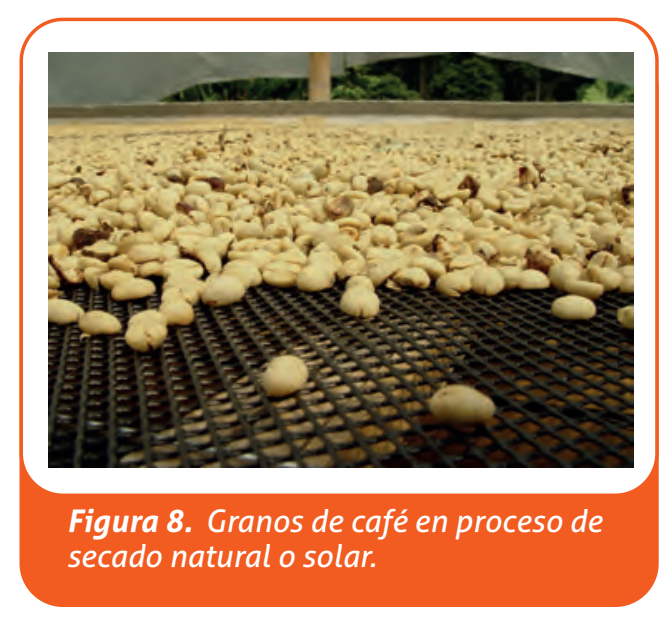

Las estructuras más utilizadas para este tipo de secado son los patios, carros y secadores parabólicos (Figura 9). Se ha establecido que para las zonas cafeteras colombianas se requiere en promedio $1,5 \mathrm{~m}^{2}$ de área de secado solar para cinco arrobas de café pergamino seco.

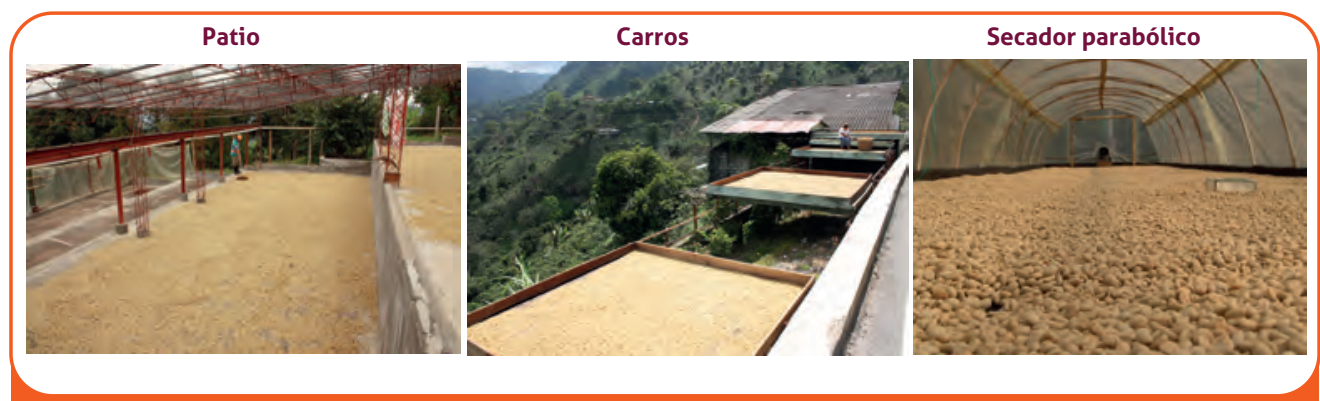

Figura 9. Estructuras empleadas para el secado solar.

En la fase inicial del secado, la capa de café debe ser lo más delgada posible, para que garantice que todos los granos tengan la misma oportunidad de tener contacto con el aire que retira la humedad. En la segunda fase, cuando el café se encuentra cerca al rango de humedad final ( $10 \%$ al $12 \%)$, se utilizan capas de máximo $2 \mathrm{~cm}$ de altura, para garantizar la uniformidad de la humedad en todos los granos del café.

Durante el secado deben realizarse por lo menos cuatro volteos del café al día, para permitir que todos los granos tengan el mismo contacto con el sol y el aire. Se recomienda utilizar el rastrillo Cenicafé, debido a que este garantiza un mejor volteo del café.

Son muchas las variables que tienen incidencia directa en la duración de este tipo de secado: la radiación solar, la temperatura, la humedad del aire, el contenido de humedad del grano, el tipo de material del secador, el espesor de la capa, el procedimiento y periodicidad para revolver los granos, por tal motivo no pueden establecerse tiempos fijos de finalización del mismo. Los menores tiempos de secado (3 a 7 días) se han obtenido con un promedio de brillo solar superior a $5 \mathrm{~h}$ /día, con altura de capa máxima de café lavado de $2 \mathrm{~cm}$ (13 kg de café lavado por metro cuadrado), revolviendo el café por lo menos cuatro veces al día. 
Para determinar la humedad final del grano durante el proceso de secado, tradicionalmente se utilizan métodos subjetivos como la dureza y el color del grano, con los cuales se corre el riesgo de obtener contenidos de humedad por fuera del rango, que afectan la calidad, inocuidad y el precio del café. Oliveros et al. (2009) desarrollaron el método Gravimet, con el cual se determina el contenido de humedad durante el proceso de secado, empleando una canastilla con una muestra de control de $200 \mathrm{~g}$ de café lavado, la cual se ubica en las mismas condiciones del resto de café. El peso del café en la canastilla se verifica a medida que transcurre la pérdida de agua, hasta que alcanza un valor entre 104 a $105 \mathrm{~g}$ (Figura 10), valor que indica que la humedad del café está en el rango deseado del $10 \%$ a $12 \%$.

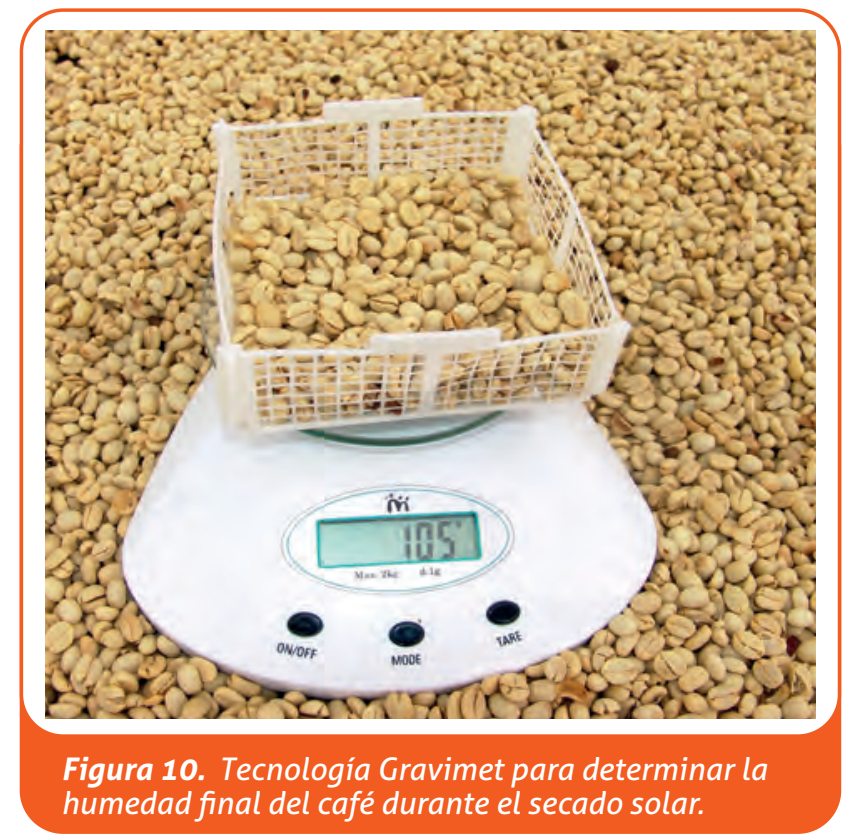

Secado mecánico. El secado mecánico consiste en hacer pasar a través de una capa de café un volumen de aire determinado, impulsado por un ventilador y calentado en forma indirecta, a una temperatura no mayor a $50^{\circ} \mathrm{C}$. La capa de secado debe tener máximo $40 \mathrm{~cm}$ y estar nivelada, adicionalmente el flujo de aire debe intercambiarse cada seis horas, para garantizar una mayor uniformidad en el secado. El cálculo de la cantidad de aire que debe circular por el espacio intergranular es importante, pues de este depende la transferencia de calor necesaria para producir la evaporación y retirar el vapor de agua de los granos.

El caudal específico de aire es de vital importancia para el éxito de la operación de secado. Si es insuficiente, se incrementa el tiempo de secado y los granos presentan alta variación en el contenido final de humedad. Por otro lado, si el caudal es mayor de lo necesario, se incrementarán los costos del secado, debido a una potencia superior del ventilador $\mathrm{y}$, por consiguiente, un mayor consumo de energía. 
La calidad del café se determina por el conjunto de características químicas, microbiológicas, físicas y organolépticas (Figura 11), que motivan a un comprador a pagar un precio mayor por el producto, lo que representa un mejor ingreso y mayor rentabilidad para el caficultor.

Para la evaluación de la calidad de un producto se requiere del conocimiento de las propiedades y cualidades que permiten clasificarlo dentro de los valores de calidad, así como aquello que constituye un defecto o una característica no aceptable para el consumo. El análisis físico y sensorial del café describe las principales características de la calidad del café que comprende: los granos negros, vinagres, flojos, aplastados, granos excelsos, entre otros granos, y las sensoriales como aroma, cuerpo, acidez.

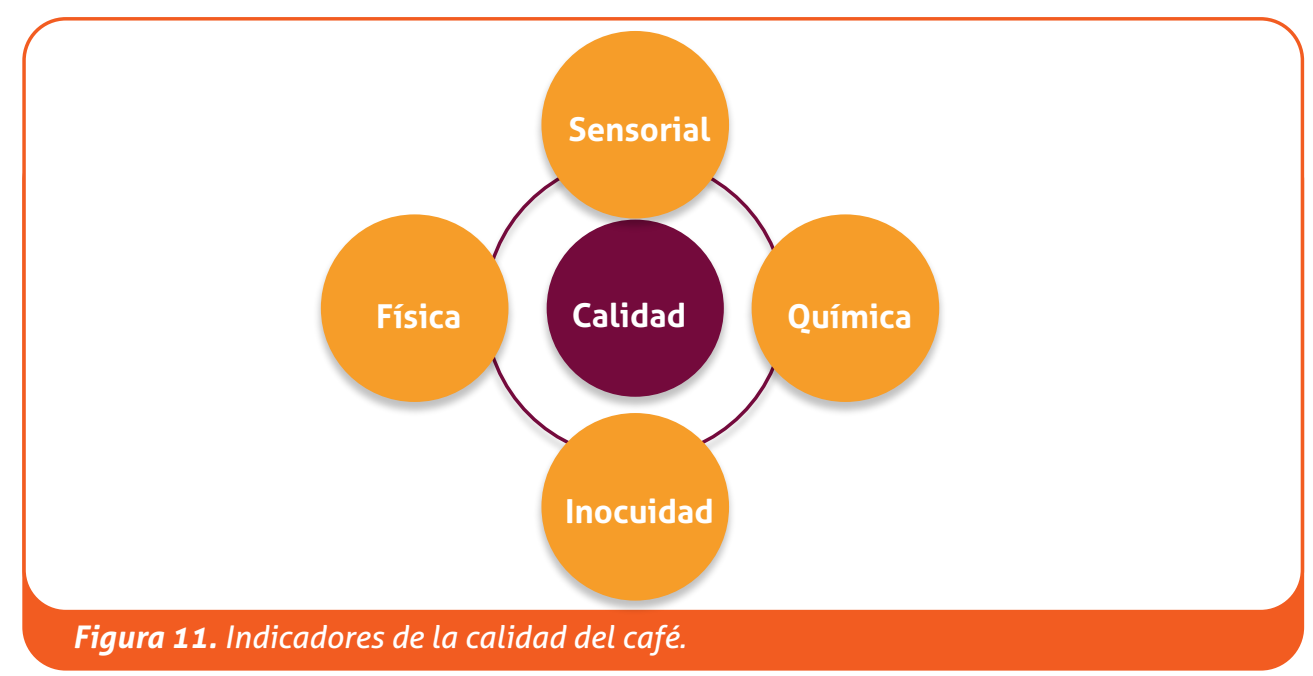

\section{Análisis físico de café pergamino seco}

La calidad física del café se establece a través de examen visual, con una valoración de los defectos del café verde, así como la evaluación de su aspecto general. La calidad física del café se define como la cantidad de almendra sana, libre de granos que no cumplen con los requisitos exigidos por los cafés tipo exportación.

En Colombia se considera el porcentaje de humedad del café pergamino seco (10\%$12 \%)$ como requisito para la compra de café, y se evalúa el porcentaje de almendra sana o factor de rendimiento (Figura 12). El precio del café obtenido en la comercialización depende de la calidad del café que se lleve al punto de compra.

Los aspectos más importantes evaluados dentro de la calidad física del café son:

- Porcentaje de humedad: debe estar entre el rango de 10\% al 12\%.

- Porcentaje de almendra sana: es la cantidad de granos sanos, sin algún defecto presente en una cantidad determinada de café.

- Factor de rendimiento: es la cantidad de café pergamino seco que se necesita para obtener un saco de 70 kilogramos de café excelso. Actualmente, el promedio del factor de rendimiento en el país es de 92,8, que corresponden a 92,8 kg de café pergamino seco para obtener $70 \mathrm{~kg}$ de café excelso. Lo restante corresponde a cisco y defectos (Figura 12). 


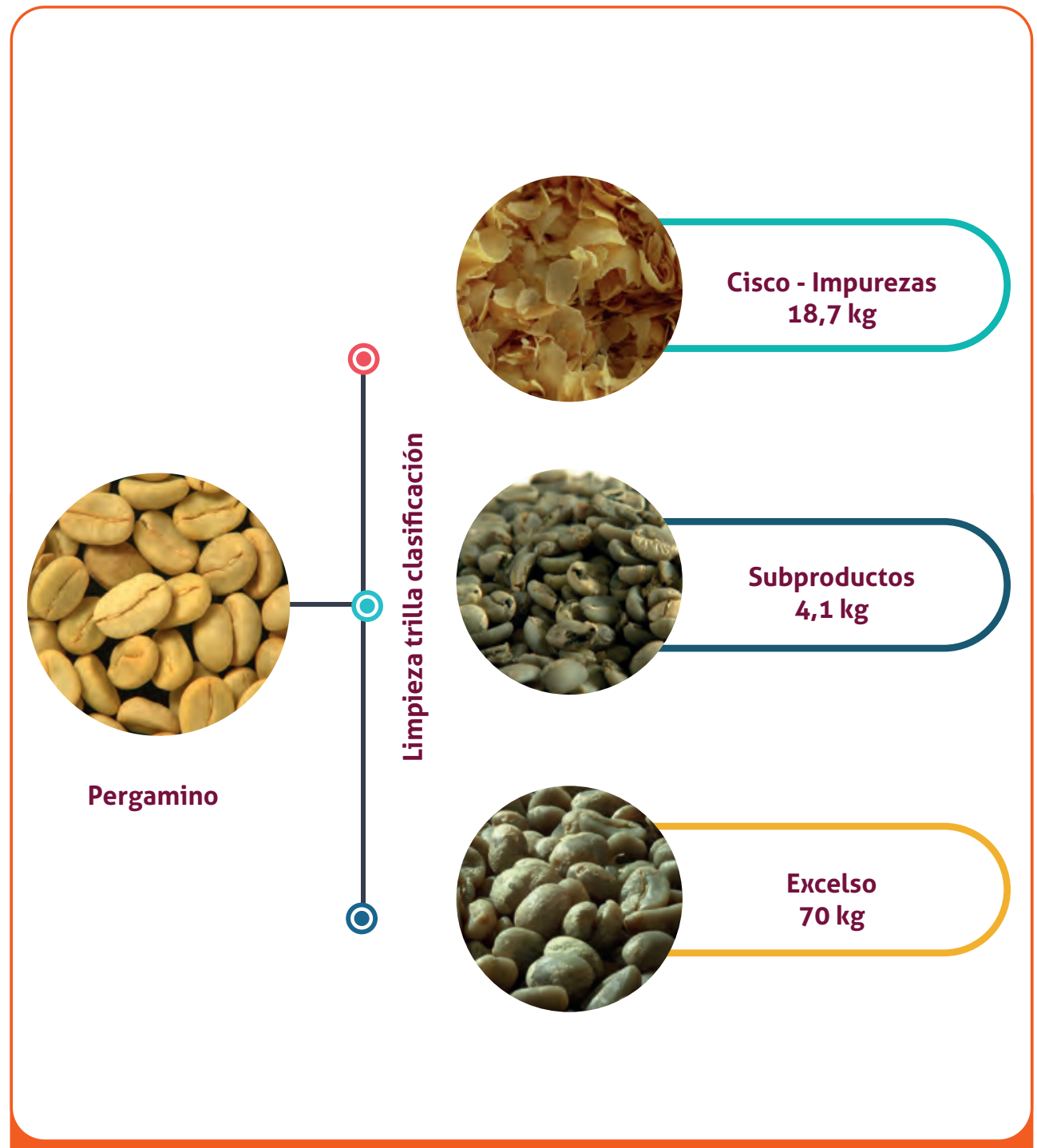

Figura 12. Componentes del factor de rendimiento en trilla.

Los defectos del café verde se clasifican en defectos del primer y segundo grupo. Entre los defectos del primer grupo se encuentran: negro total o parcial, cardenillo total o parcial, vinagre o parcialmente vinagre, reposado y ámbar o mantequillo. Entre los defectos del segundo grupo o menores están: cristalizado, decolorado veteado, decolorado sobresecado, mordido o cortado, picado por insectos, averanado o arrugado, ligeramente picado por broca, averanado, aplastado y grano flojo. En la Tabla 1 se presentan las descripciones de los defectos físicos del café, su definición y sus posibles causas. 


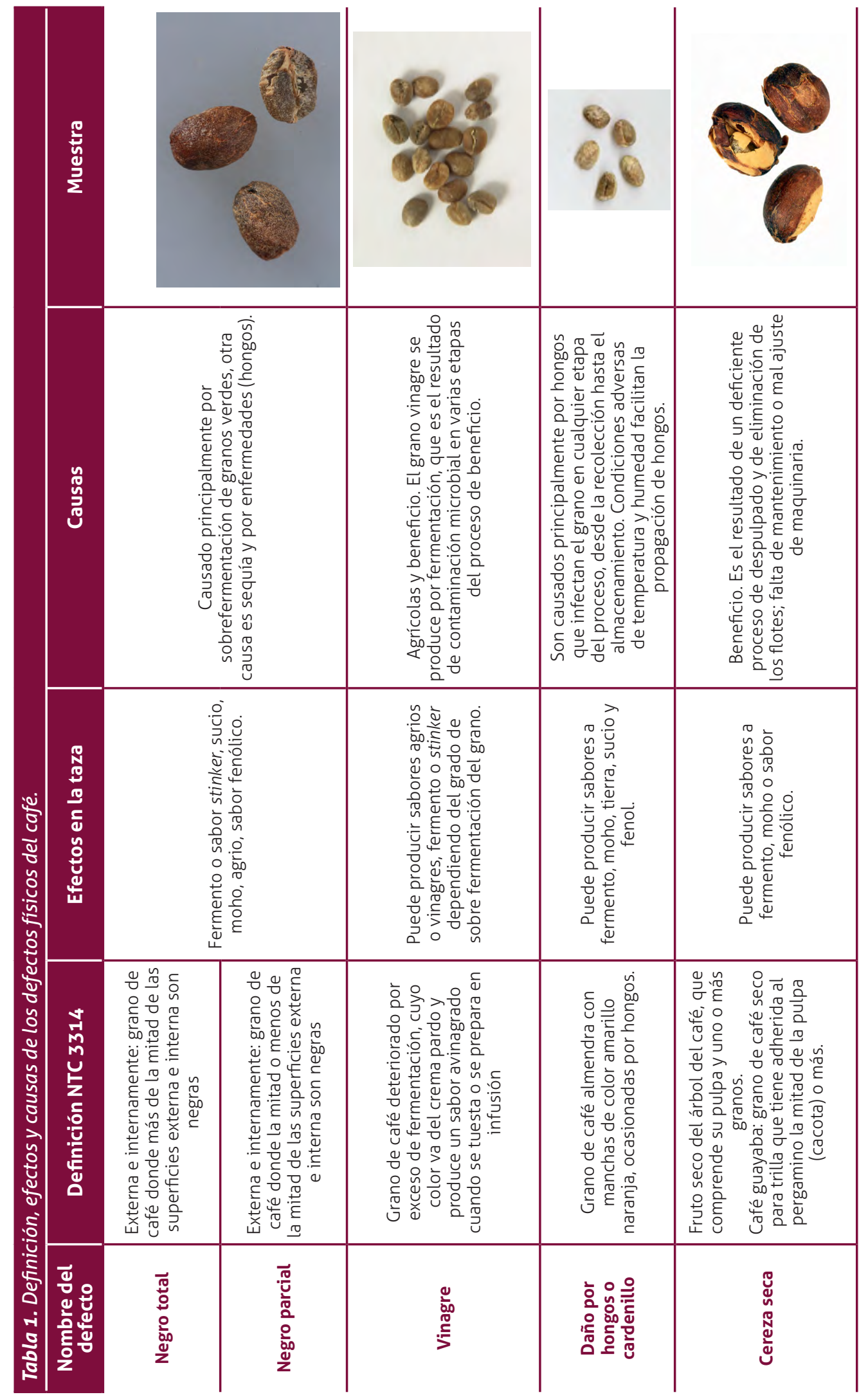




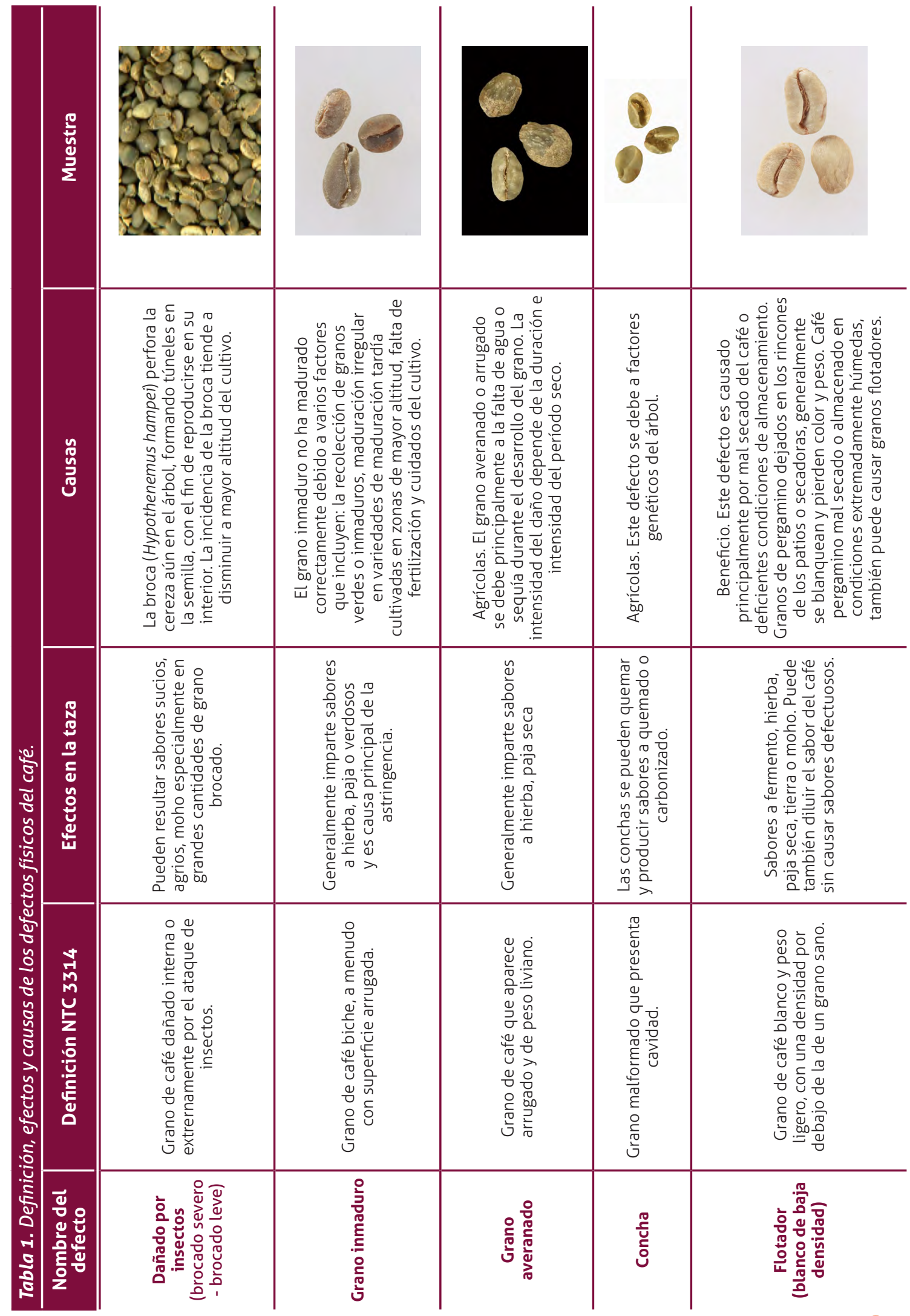




\section{Análisis sensorial de café}

El análisis sensorial, es decir, el estudio de aquellas propiedades de los alimentos que afectan los órganos de los sentidos, es hasta ahora el método más eficiente para evaluar la calidad del café.

Las características de color, aspecto, olor y sabor de los alimentos, estimulan la visión, el olfato, el tacto y el gusto, produciendo estímulos que van al cerebro, donde ocurre la percepción o correlación de impresiones sensoriales, convirtiéndose en un juicio por medio del cual se determina si un producto es aceptado o rechazado.

Para este tipo de análisis es importante señalar que el ser humano resulta imprescindible como "instrumento de medida". Con sus sentidos es capaz de detectar componentes situados muy por debajo de la capacidad de medición de los instrumentos analíticos. Con su interpretación y su valoración, el hombre puede comunicar más datos sobre un producto que el más sensible de los procesos analíticos.

La catación tiene los siguientes objetivos:

- Definir si el café tiene defectos o sabores desagradables.

- Describir los atributos y los sabores agradables.

- Evaluar su intensidad.

- Decidir si el café es malo, regular, promedio, bueno, muy bueno o sobresaliente.

- Informar sobre los resultados obtenidos.

\section{Atributos sensoriales del café (SCA, 2015)}

- Fragancia/aroma: los aspectos aromáticos incluyen la fragancia (definida como el olor del café de la muestra molida cuando todavía está seca), y el aroma (olor del café mezclado con agua caliente).

- Sabor: el sabor representa la característica principal de café, es una impresión combinada del sabor y el aroma.

- Sabor residual: se define como la duración de las cualidades positivas del sabor que se perciben en la parte posterior del paladar.

- Acidez: se describe como aquella sensación en la lengua que hace salivar. A menudo se describe como "brillante" cuando es favorable o "agria" cuando es desfavorable.

- Cuerpo: La calidad del cuerpo se basa en la sensación de pesadez del líquido en la boca, especialmente cómo se percibe entre la lengua y el paladar superior de la boca.

- Balance (o equilibrio): es el resultado del complemento o contraste de los diferentes aspectos del sabor del café como son acidez, sabor residual y cuerpo de la muestra. 
Los defectos son los sabores negativos que generan el rechazo del café. En la Tabla 2 se presentan las descripciones de los defectos en el sabor del café.

\begin{tabular}{|c|c|c|}
\hline Grupo & Defecto & Definición NTC 2758 \\
\hline \multirow{4}{*}{ 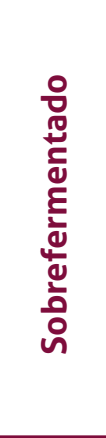 } & Pulpa & $\begin{array}{l}\text { 4.29. Aroma y sabor que da en la bebida un gusto al fruto de café } \\
\text { sobremaduro, que evoca el aroma a la pulpa fresca. }\end{array}$ \\
\hline & Vinagre & $\begin{array}{l}\text { 4.77. Sensación olfativa y gustativa diferente a la de la acidez natural, } \\
\text { caracterizada por la descomposición intermedia a ácido acético, } \\
\text { generalmente ocasionada por una fermentación excesiva. }\end{array}$ \\
\hline & Fermento & $\begin{array}{l}\text { 4.48. Sensación olfativa y gustativa a materia orgánica descompuesta, } \\
\text { indeseable en el café. Producido en la sobrefermentación enzimática de } \\
\text { compuestos orgánicos durante el beneficio. }\end{array}$ \\
\hline & Stinker & $\begin{array}{l}\text { 4.50. Sensación de aroma y sabor fuerte y defectuoso a materia orgánica } \\
\text { putrefacta, se origina por una excesiva sobrefermentación de las cerezas del } \\
\text { café o deficientes condiciones de su beneficio. }\end{array}$ \\
\hline \multirow{3}{*}{$\frac{0}{\text { 은 }}$} & Acre & $\begin{array}{l}\text { 4.28. Sensación olfativa y gustativa áspera, amarga, astringente, picante } \\
\text { y pesada. Suele estar asociada a la presencia de granos defectuosos } \\
\text { especialmente negros. }\end{array}$ \\
\hline & Áspero & $\begin{array}{l}\text { 4.36. Sensación táctil fuerte, rasposa y tosca, indeseable en el café, } \\
\text { causada por presencia de granos defectuosos, deficiencias en el proceso de } \\
\text { industrialización, deterioro del café tostado o preparación de la bebida. }\end{array}$ \\
\hline & Inmaduro & $\begin{array}{l}\text { 4.53. Percepción de aroma y sabor que puede ser ocasionada por la presencia } \\
\text { de frutos de café verdes y pintones que producen tazas astringentes, } \\
\text { agresivas y que no tienen características organolépticas desarrolladas. }\end{array}$ \\
\hline \multirow{5}{*}{ 온 } & Sucio & $\begin{array}{l}\text { 4.73. Sensación de aroma y sabor asociada a polvo, pesada en el paladar } \\
\text { e indeseable en el café. Originado por deficiencias de la limpieza en el } \\
\text { beneficio y almacenamiento del café verde y pergamino. }\end{array}$ \\
\hline & Paja & $\begin{array}{l}\text { 4.62. Sensación de aroma y sabor característica a hierba o grama seca o } \\
\text { heno, puede presentarse en cafés frescos deficientemente secados o por la } \\
\text { transformación de material orgánico durante su almacenamiento. }\end{array}$ \\
\hline & Mohoso & $\begin{array}{l}\text { 4.58. Aroma y sabor indeseable del café, característico a moho que se } \\
\text { desarrolla por el inadecuado manejo de la humedad durante el beneficio, en } \\
\text { especial en el secado del café y durante su almacenamiento. }\end{array}$ \\
\hline & Terroso & $\begin{array}{l}\text { 4.74. Aroma y sabor a tierra húmeda o recién movida, indeseable en los cafés } \\
\text { arábigos; en algunos casos se asocia al hollejo de la papa. Esta característica } \\
\text { se puede presentar por un secado inadecuado del café sobre tierra durante el } \\
\text { beneficio. }\end{array}$ \\
\hline & Reposo & $\begin{array}{l}\text { 4.98. Sabor y aroma característico de café verde, que debido al tiempo y } \\
\text { condiciones de almacenamiento han hecho que las características de aroma } \\
\text { y sabor, especialmente la acidez, hayan disminuido. En el caso de café fresco } \\
\text { esta característica se considera un defecto. Cuando aparecen leves notas de } \\
\text { reposo en un café, la sensación es denominada como ligero reposo (oldish). }\end{array}$ \\
\hline
\end{tabular}

\section{Continúa...}


Tabla 2. Definiciones de los defectos sensoriales del café.

\begin{tabular}{|c|c|c|}
\hline Grupo & Defecto & Definición NTC 2758 \\
\hline \multirow{6}{*}{ 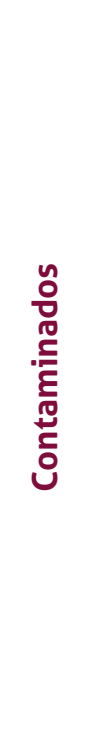 } & Humo & $\begin{array}{l}\text { 4.32. Sensación olfativa asociada a la presencia de humo que se impregna } \\
\text { en el café en cualquier etapa, desde el beneficio hasta la preparación de la } \\
\text { bebida, debida a condiciones inadecuadas. }\end{array}$ \\
\hline & Combustible & $\begin{array}{l}\text { 4.42. Característica que presenta el café por contaminación con derivados } \\
\text { del petróleo como ACPM o gasolina durante su beneficio, transporte, } \\
\text { almacenamiento o torrefacción. }\end{array}$ \\
\hline & Fenol & $\begin{array}{l}\text { 4.47. Aroma y principalmente sabores indeseables en el café, asociado a } \\
\text { compuestos halogenados (con cloro, yodo). Se puede generar durante el } \\
\text { beneficio por lavado con aguas cloradas o con residuos de desinfectantes, o } \\
\text { por rehumedecimiento del café durante el secado. }\end{array}$ \\
\hline & Metálico & $\begin{array}{l}\text { 4.57. Sensación gustativa similar a la que toma el agua en contacto directo } \\
\text { con superficies metálicas recién pulidas. Indeseable en el café, puede } \\
\text { presentarse por el agua o los recipientes utilizados en la preparación de la } \\
\text { bebida. }\end{array}$ \\
\hline & Químico & $\begin{array}{l}\text { 4.68. Aroma y sabor a compuestos químicos como desinfectantes o } \\
\text { medicinales, característicos de los hospitales e indeseables en el café. Se } \\
\text { pueden generar en cafés muy tostados. }\end{array}$ \\
\hline & $\begin{array}{l}\text { Contaminado- } \\
\text { No identificado } \\
\text { (extraño) }\end{array}$ & $\begin{array}{l}\text { 4.60. Característica de sabor y aroma indeseables en el café que no se puede } \\
\text { definir. }\end{array}$ \\
\hline
\end{tabular}

\section{Composición química del café verde}

La composición química del café almendra determina la calidad final del producto, por lo cual es importante conocer el contenido de los principales precursores químicos que afectan la bebida. La cafeína es estable al calor y se asocia generalmente con el sabor amargo distintivo del café (Perrone et al., 2008). La trigonelina es un alcaloide cuya importancia está relacionada con su degradación durante el proceso de tostión, para dar varios compuestos volátiles que influyen en el aroma la bebida (Caporaso et al., 2018).

Los perfiles volátiles $y$, posteriormente, los perfiles aromáticos y las cualidades sensoriales del café tostado dependen en gran medida de la composición de los precursores de aromas presentes en los granos de café verde antes de la tostión. Esto fue corroborado por estudios que demostraron que las diferencias en las concentraciones de precursores de aromas como las proteínas, carbohidratos y ácidos clorogénicos en los granos de café verde, de la misma variedad, correspondió a diferentes calidades después del tostado (Franca et al., 2005).

Los ácidos clorogénicos son compuestos fenólicos que influyen en la formación del aroma, astringencia y amargo. La sacarosa, compuesto más abundante, actúa como precursor del aroma, originando varias sustancias en el proceso de tostión, debido a las reacciones de Maillard que afectan el sabor y aroma de la bebida. La presencia de lípidos se asocia con la duración del aroma y la espuma de la bebida, y su acumulación depende de varios factores, particularmente de la especie (Tabla 3). 


\begin{tabular}{|c|c|c|c|}
\hline Compuesto & $\begin{array}{l}\text { Rango café } \\
\text { arábica verde } \\
\text { ( } \% \text { base seca) }\end{array}$ & $\begin{array}{l}\text { Influencia en } \\
\text { los atributos } \\
\text { sensoriales }\end{array}$ & Fuente \\
\hline \multirow{3}{*}{ Sacarosa } & $5,3-9,3$ & \multirow{3}{*}{$\begin{array}{c}\text { Precursor del sabor, aroma, } \\
\text { acidez y color }\end{array}$} & Clifford, 1985 \\
\hline & $6,25-8,45$ & & Clarke y Macrae,1985 \\
\hline & 8,0 & & Puerta, 2011 \\
\hline \multirow{4}{*}{ Cafeína } & $0,6-1,5$ & \multirow{4}{*}{ Amargo } & Clifford, 1985 \\
\hline & $0,9-1,2$ & & Clarke y Macrae, 1985 \\
\hline & $1,7 \pm 0,02$ & & Franca et al. (2005) \\
\hline & 1,20 & & Puerta, 2011 \\
\hline \multirow{5}{*}{ Trigonelina } & 1,0 & \multirow{5}{*}{ Precursor del aroma } & Clifford, 1985 \\
\hline & $1,0-1,2$ & & Clarke y Macrae, 1985 \\
\hline & $0,64 \pm 0,28$ & & Franca et al. (2005) \\
\hline & $1,34 \pm 0,5$ & & Farah, 2005 \\
\hline & 1,0 & & Puerta, 2011 \\
\hline \multirow{3}{*}{$\begin{array}{c}\text { Ácidos } \\
\text { clorogénicos }\end{array}$} & $5,5-8,0$ & \multirow{3}{*}{$\begin{array}{c}\text { Acidez, astringencia y } \\
\text { amargo }\end{array}$} & Clarke y Macrae,1985 \\
\hline & $6,2-7,9$ & & Clifford, 1985 \\
\hline & 6,90 & & Marín y Puerta, 2008 \\
\hline \multirow{4}{*}{ Lípidos } & $10-14$ & \multirow{4}{*}{$\begin{array}{l}\text { Precursores del sabor y } \\
\text { cuerpo de la bebida }\end{array}$} & Clifford, 1985 \\
\hline & $12,0-18$ & & Clarke y Macrae, 1985 \\
\hline & $11,13 \pm 0,13$ & & Franca et al. (2005) \\
\hline & 16,2 & & Puerta, 2011 \\
\hline Minerales & $3,0-4,2$ & - & Clarke y Macrae, 1985 \\
\hline
\end{tabular}

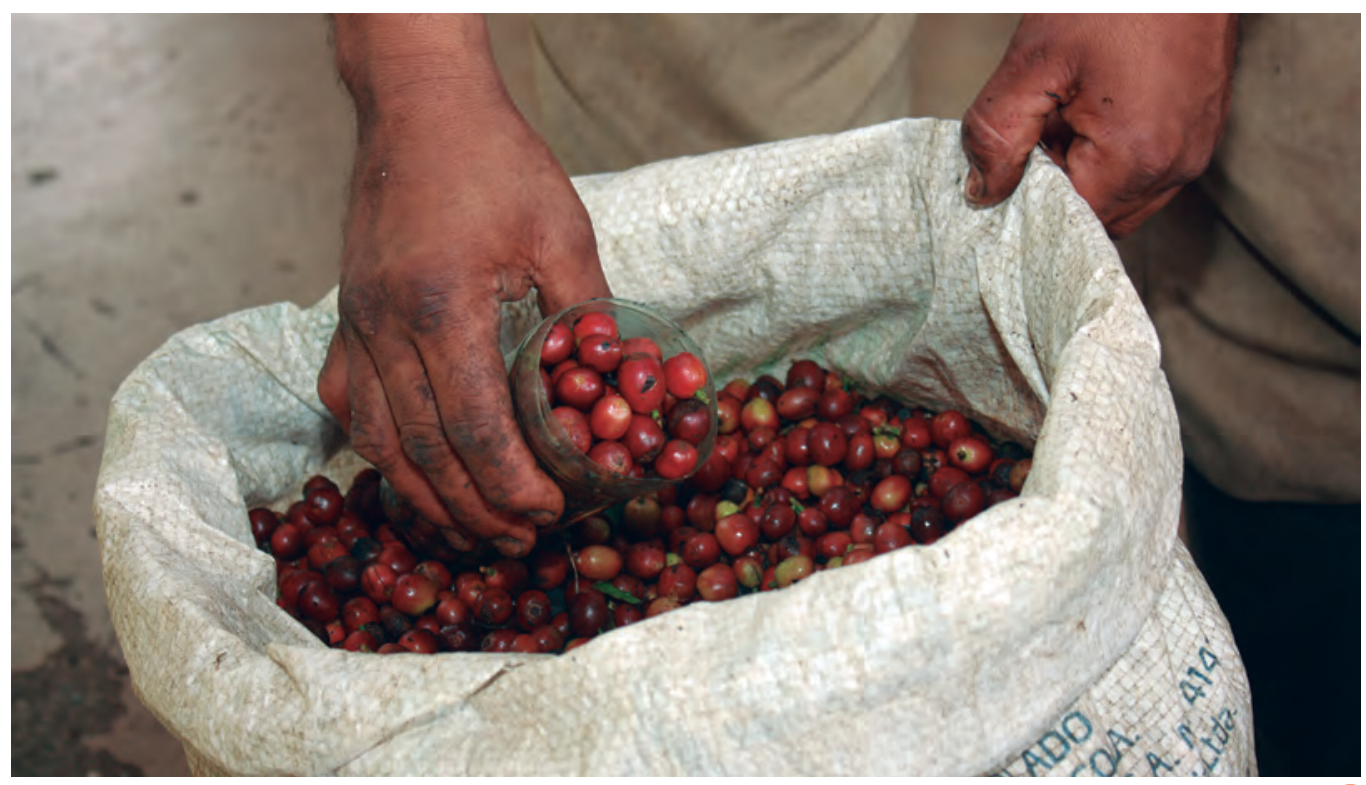




\section{Descripción de las fincas participantes en la caracterización de la calidad del Huila}

En total se analizaron 562 muestras de café, procedentes de los 35 municipios cafeteros del Huila (Tabla 4).

\begin{tabular}{|c|c|c|c|}
\hline Municipio & Número de muestras & Municipio & Número de muestras \\
\hline Acevedo & 47 & Neiva & 14 \\
\hline Agrado & 5 & Oporapa & 16 \\
\hline Aipe & 5 & Paicol & 10 \\
\hline Algeciras & 20 & Palermo & 10 \\
\hline Altamira & 5 & Palestina & 20 \\
\hline Baraya & 5 & Pital & 18 \\
\hline Campoalegre & 10 & Pitalito & 60 \\
\hline Colombia & 10 & Rivera & 5 \\
\hline Elías & 5 & Saladoblanco & 15 \\
\hline Garzón & 33 & San Agustín & 25 \\
\hline Gigante & 19 & Santamaría & 10 \\
\hline Guadalupe & 19 & Suaza & 25 \\
\hline Hobo & 5 & Tarqui & 11 \\
\hline Íquira & 10 & Tello & 14 \\
\hline Isnos & 15 & Teruel & 10 \\
\hline La Argentina & 10 & Tesalia & 5 \\
\hline La Plata & 43 & Timaná & 18 \\
\hline Nataga & 10 & Total & 562 \\
\hline
\end{tabular}

\section{Caracterización técnica de las fincas}

El promedio de área en café de las 123 fincas del muestreo fue de 6,0 ha, el valor mínimo fue de 0,24 ha y el máximo de 98,0 ha. El 36,3\% de las fincas presentaron menos de 3 ha en café (Figura 13). 


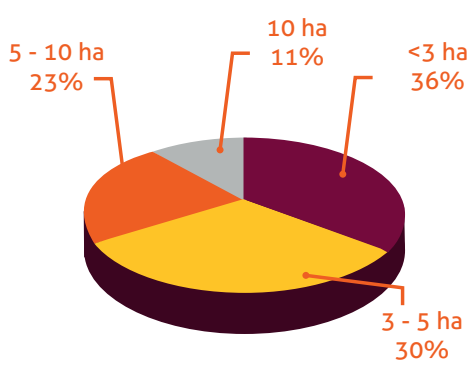

Figura 13. Distribución de las fincas según el área en café.

El $73 \%$ de las fincas participantes tenían establecidos cafetales con variedades resistentes a la roya de cafeto, como Castillo®, Colombia y Tabi (Figura 14). El 28\% de las fincas se ubicaban a altitudes por encima de $1.700 \mathrm{~m}$, el 70\% entre 1.300 y $1.700 \mathrm{~m}$, y el $2 \%$ por debajo de $1.300 \mathrm{~m}$ (Figura 15).

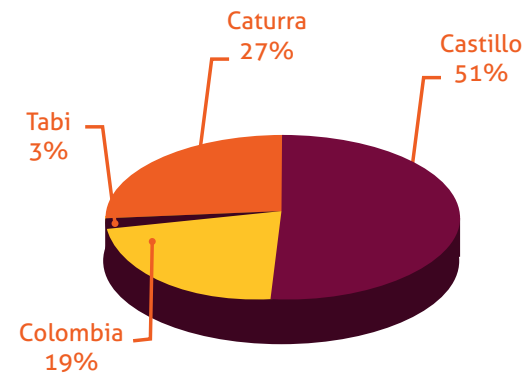

Figura 14. Distribución de las fincas según la variedad de café cultivada.

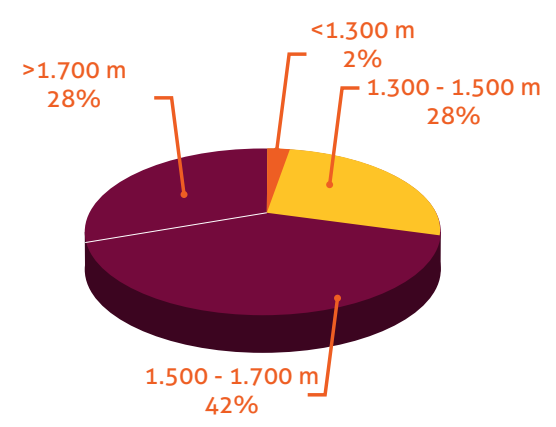

Figura 15. Distribución de las fincas según la altitud. 
Las variables de la calidad física del café que se midieron incluyeron la humedad del café pergamino seco, la merma, la proporción de grano brocado, pasilla, almendra sana y el factor de rendimiento en trilla, se midieron según los métodos de análisis de Almacafé. Los promedios indican que las variables físicas permiten el cumplimiento de los requisitos de calidad del café, aumentando la posibilidad de los caficultores de vender su producto a un mayor precio (Tabla 5).

\begin{tabular}{|c|c|c|c|c|}
\hline \multirow{2}{*}{ Variable } & \multicolumn{2}{|c|}{ Valores observados } & \multirow{2}{*}{ Promedio } & \multirow{2}{*}{ Mediana } \\
\hline & Mínimo & Máximo & & \\
\hline Humedad (\%) & 9,2 & 13,7 & 11,3 & 11,3 \\
\hline Merma (\%) & 16,2 & 21,5 & 18,3 & 18,3 \\
\hline Pasilla (\%) & 0,0 & 8,6 & 1,1 & 0,9 \\
\hline Broca (\%) & 0,0 & 10,6 & 1,5 & 1,0 \\
\hline Almendra sana (\%) & 69,0 & 83,3 & 79,6 & 80,0 \\
\hline Factor de rendimiento & 84,5 & 103,0 & 88,9 & 88,1 \\
\hline
\end{tabular}

En cuanto a la variable tamaño del grano de café almendra, según la distribución granulométrica, el 88\% del café analizado se retuvo en mallas superiores a la 16 (Figura 16).

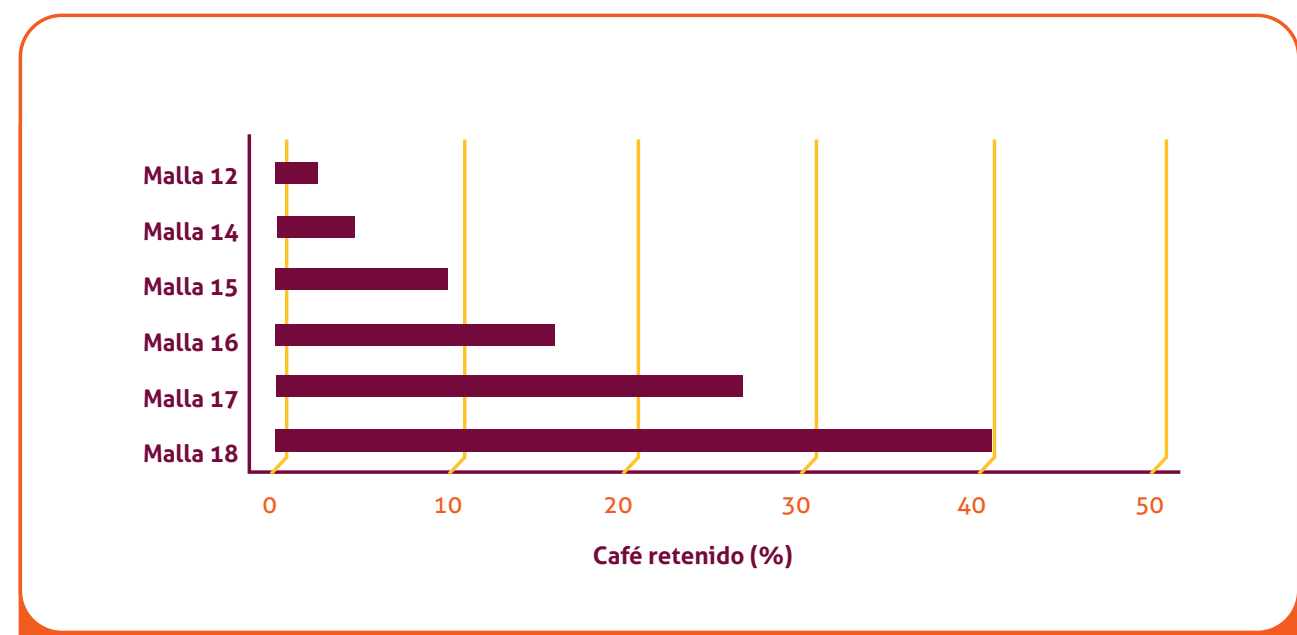

Figura 16. Distribución granulométrica del café almendra.

\section{Resultados de la medición de la calidad química}

El café es sin duda uno de los productos alimenticios más complejos desde el punto de vista de su composición química. No solo porque el grano verde contiene una amplia gama de diferentes compuestos químicos, sino porque estos compuestos reaccionan e interactúan en las diferentes etapas del procesamiento del café, generando una diversidad y complejidad de estructuras aún mayor (Clarke y Macrae, 1985). 
Para las 562 muestras analizadas en la (Tabla 6) se presentan los valores obtenidos para ácidos clorogénicos, cafeína, lípidos, sacarosa y trigonelina, por tecnología NIRS.

\begin{tabular}{|c|c|c|c|c|}
\hline \multirow{2}{*}{ Variable } & \multicolumn{2}{|c|}{ Valores Observados } & \multirow{2}{*}{ Promedio } & \multirow{2}{*}{ Mediana } \\
\hline & Mínimo & Máximo & & \\
\hline Ácidos clorogénicos & 5,4 & 6,5 & 5,9 & 5,9 \\
\hline Cafeína & 1,1 & 1,4 & 1,3 & 1,3 \\
\hline Lípidos & 13,6 & 16,4 & 15,2 & 15,3 \\
\hline Sacarosa & 6,0 & 7,1 & 6,5 & 6,5 \\
\hline Trigonelina & 0,8 & 1,4 & 1,1 & 1,1 \\
\hline
\end{tabular}

\section{Resultados de la medición de la calidad sensorial}

Las muestras fueron evaluadas con la escala de Almacafé, en la Tabla 7 se presenta la clasificación de acuerdo con el puntaje obtenido.

\begin{tabular}{|c|c|}
\hline Calificación & Intervalos de valoración \\
\hline Defectuoso & $<4,0$ \\
\hline Deficiente & $4,0-4,5$ \\
\hline Estándar & $5,0-5,5$ \\
\hline Bueno & $6,0-6,5$ \\
\hline Muy bueno & $7,0-7,5$ \\
\hline Excelente & $8,0-8,5$ \\
\hline Excepcional & $9,0-9,5$ \\
\hline Máximo & 10 \\
\hline
\end{tabular}

Las cifras consolidadas de calidad sensorial indican que del total de muestras evaluadas el $79 \%$ no presentaron defecto. De los diferentes defectos de taza analizados (químico, fenol, fermento, stinker, vinagre, reposo, otros), los más recurrentes fueron: reposo, acre, inmaduro y fermento (Figura 17), relacionados con un inadecuado beneficio, manejo y almacenamiento del café. 


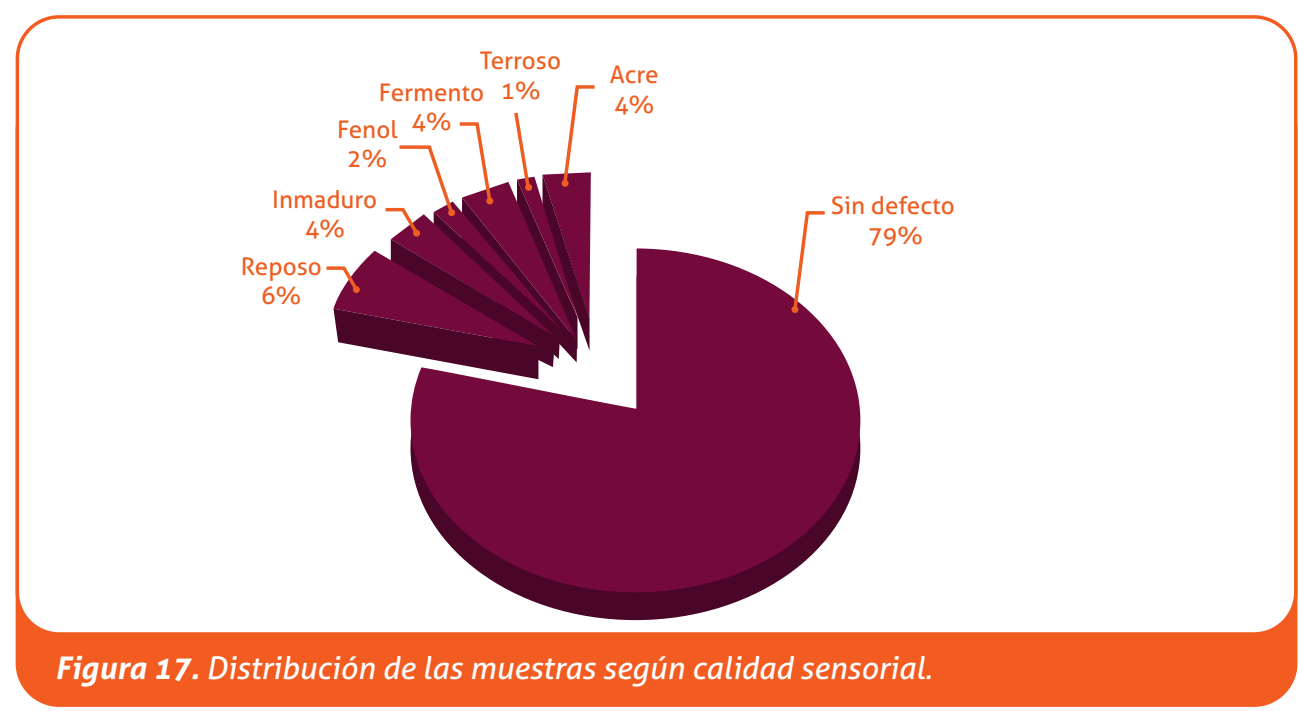

De las muestras que no presentaron defecto, en promedio para todos los atributos, la calificación obtenida estuvo por encima de 5,0 puntos, que corresponde a una calificación de café estándar (Tabla 8).

\begin{tabular}{|c|c|c|c|}
\hline Atributo & Promedio & Valor máximo & Valor mínimo \\
\hline Fragancia y aroma & 5,22 & 8,00 & 4,00 \\
\hline Acidez & 5,28 & 7,50 & 4,00 \\
\hline Cuerpo & 5,09 & 7,50 & 4,00 \\
\hline Impresión global & 5,33 & 7,50 & 4,50 \\
\hline
\end{tabular}

\section{Descriptores sensoriales}

A cada una de las muestras analizadas que no presentaron defecto, se le asignó un descriptor de la calidad sensorial, en la Tabla 9, se presenta la proporción de los descriptores obtenidos por año de estudio, donde las notas dulce son el principal descriptor del café evaluado, seguido de notas cítricas, frutales, caramelo, floral, herbal, miel y avellanas.

Tabla 9. Proporción y representación gráfica de los de descriptores de la calidad sensorial del café del Huila.

\begin{tabular}{c|c|c|c|c|}
\hline Descriptor & \multicolumn{3}{|c|}{ Año } & General \\
& $\mathbf{2 0 1 6}$ & $\mathbf{2 0 1 7}$ & $\mathbf{2 0 1 8}$ & \\
\hline Dulce & $61,3 \%$ & $71,1 \%$ & $52,9 \%$ & $61,8 \%$ \\
\hline Cítrica & $7,5 \%$ & $13,3 \%$ & $21,2 \%$ & $14,0 \%$ \\
\hline Frutal & $7,5 \%$ & $2,4 \%$ & $3,5 \%$ & $4,5 \%$ \\
\hline Caramelo & $6,3 \%$ & $6,0 \%$ & $11,8 \%$ & $8,0 \%$ \\
\hline Floral & $6,3 \%$ & $2,4 \%$ & $2,4 \%$ & $3,7 \%$ \\
\hline Herbal & $5,0 \%$ & $2,4 \%$ & $7,1 \%$ & $4,8 \%$ \\
\hline Miel & $4,4 \%$ & $2,4 \%$ & $1,2 \%$ & $2,7 \%$ \\
\hline Avellanas & $1,9 \%$ & $0,0 \%$ & $0,0 \%$ & $0,6 \%$ \\
\hline
\end{tabular}




\section{Denominación de Origen}

La FNC en su Plan Estratégico 2008-2012 propuso posesionar el café de Colombia y su portafolio marcario, avanzando en la implementación de una estrategia de diferenciación de los cafés por su origen.

Esta estrategia, innovadora en términos científicos y técnicos, busca segmentar la oferta de café de acuerdo con los atributos físicos, químicos, sensoriales y culturales asociados a su origen regional, de manera que los cafés de Colombia se conviertan en un referente cultural y un activo intangible de gran valor en el mercado.

Esta iniciativa empezó en marzo de 2005, cuando el Gobierno Colombiano aprobó la solicitud de la FNC de reconocer la Denominación de Origen el "Café de Colombia". Adicionalmente, en septiembre de 2007, la Unión Europea otorgó la Indicación Geográfica Protegida al "Café de Colombia", después de una evaluación de la capacidad institucional y sistemas de control de la FNC; así como las características sociales y ambientales relacionadas al "Café de Colombia".

Para garantizar la sostenibilidad del Café de Colombia y sus regiones, se desarrollaron estudios técnicos con los cuales se logró que la Superintendencia de Industria y Comercio concedió la Denominación de Origen para las siguientes regiones cafeteras del país: Cauca (2011), Nariño (2011), Huila (2013), Santander (2014), Tolima (2015) y Café de la Sierra Nevada (Cesar, La Guajira y Magdalena) en el año 2015.

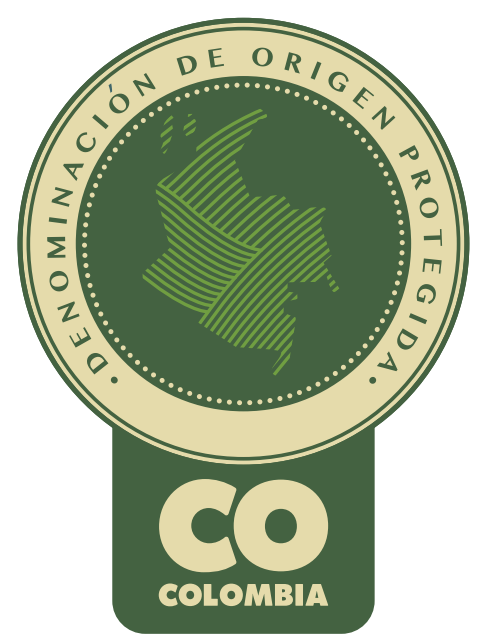




\section{Literatura citada}

Asociación de Cafés Especiales de America. (SCA). Protocols Cupping Specialty Coffee. Retrieved From Http://Www.Scaa.Org/Pdf/Resources/Cupping-Protocols.Pdf. 2015.

Caporaso, N.; Whitworth, M.; Grebby, S.; Fisk, I. (2018). Non-destructive Analysis of Sucrose, Caffeine and Trigonelline On Single Green Coffee Beans By Hyperspectral Imaging. Food Research International (106):193-203.

Centro Nacional de Investigaciones de Café, Cenicafé (1991). Fundamentos del Beneficio del Café. Chinchiná, Caldas, Página 236.

Clarke, R. J., Macrae, R. (1985). Coffee (Vol. 1). pp. 306

Clifford, M. N. (1985). Chlorogenic Acids. En Coffee (Pp. 153-202). Springer, Dordrecht.

Días R., Benassi M. (2015). Discrimination Between Arabica and Robusta Coffees Using Hydrosoluble Compounds: Is The Efficiency of The Parameters dependent On The Roast degree? Beverages. (1): 127-139.

Farah, A. (2012). Coffee Constituents. Coffee Constituents, In Coffee: Emerging Health Effects and Disease Prevention (Ed y.-F. Chu), Wiley-Blackwell, Oxford, Uk

Franca, A. S., Mendonca, J. C. F., y Oliveira, S. D. (2005). Composition of Green and Roasted Coffees of Different Cup Qualities. Food Science and Technology. 38, 709-715.

ICONTEC. NTC 2324. (1987). Café Verde; Examen Olfativo y Visual y determinación de Materia Extraña y defectos. Bogotá (Colombia), Icontec-Cenicafé

ICONTEC. NTC 2758. (2002). Café. Análisis Sensorial. Vocabulario. Bogotá (Colombia).

ICONTEC. NTC 3314. (1992). Café y Sus Productos. Vocabulario. Términos y definiciones. Bogotá (Colombia)

Isaza G., L.E.; Montoya R., E.C.; Vélez Z., J.C.; Oliveros T., C.E. (2006). Evaluación de La Concentración de Frutos Maduros de Café Empleando Técnicas No Selectivas de Recolección Manual. Cenicafé 57(4): 274-278.

Marín L., S.M.; Arcila P., J.; Montoya R., E.C.; Oliveros T.; C.E. (2003). Relación Entre El Estado de Madurez del Fruto del Café y Las Características de Beneficio, Rendimiento y Calidad de La Bebida. Cenicafé 54(4):297-315.

Marín, C.; Puerta, G. I. (2008). Contenido de Ácidos Clorogénicos En Granos de Coffea arabica y C. canephora, Según El desarrollo del Fruto. Cenicafé (59): 7-28.

Montilla P., J.; Arcila P., J.; Aristizabal L., M.; Montoya R., C.; Puerta O.., G.I.; Oliveros T., C.E.; Cadena G. (2008). Caracterización de Algunas Propiedades Físicas y Factores de Conversión del Café durante el Proceso de Beneficio Húmedo Tradicional. Cenicafé 59 (2):120-142.

Oliveros T, C. E; Peñuela A.E. Jurado J. (2009). Controle la Humedad del Café en el Secado Solar, Utilizando el Método Gravimet. Cenicafé. Avances Técnicos 387.

Oliveros T, C. E; Roa M, G.; Sanz U, J. R; Ramírez G, C. A; Álvarez H, J. R; Roa M, G; Álvarez G, J. (1995). El desmucilaginado Mecánico del Café. Cenicafé. Avance Técnico 216. 
Oliveros T, C. E; Sanz U, J. R; Ramírez G, C. A; Tibaduiza C. (2013). Ecomill@. Tecnología de Bajo Impacto Ambiental Para El Lavado del Café. Cenicafé. Avance Técnico 432.

Pabón U., Sanz U, J. R.; Oliveros T, C. E. (2009). Manejo del Café desmucilaginado Mecánicamente. Avances Técnicos 388.

Peñuela M A.E. (2010). Estudio de la Remoción del Mucílago de Café A Través de La Fermentación Natural. Tesis de Grado. 84p

Peñuela M., A.E.; Pabón U., J.P.; Sanz U., J.R. (2013). Método Fermaestro: Para determinar La Finalización de la Fermentación del Mucílago de Café. Cenicafé. Avances Técnicos 431.

Peñuela M., A.E.; Sanz U., J.R.; Pabón U., J.P. (2012). Método Para Identificar El Momento Final de La Fermentación de Mucílago de Café. Cenicafé 63 (1): 120-131.

Perrone, D.; Donangelo, C.; Farah, A. (2008). Fast Simultaneous Analysis of Caffeine, Trigonelline, Nicotinic Acid and Sucrose In Coffee By Liquid Chromatography-Mass Spectrometry. Food Chemistry, 110(4): 1030-1035.

Puerta O-, G.I. (2011). Composición Química de Una Taza de Café. Cenicafé. Avances Técnicos 414: 1-12.

Puerta O.., G.I. (2000). Influencia de Los Granos de Café Cosechados Verdes, En La Calidad Física y Organoléptica de La Bebida. Cenicafé 51(2): 136-150.

Puerta O.., G.I. (2001). Cómo Garantizar la Buena Calidad de la bebida del Café y evitar los defectos. Cenicafé. Avances Técnico 284.

Puerta O.., G.I. (2006). La Humedad Controlada del Grano Preserva La Calidad del Café. Cenicafé. Avances Técnicos 352.

Puerta O., G.I. (2010). Fundamentos del Proceso de Fermentación En El Beneficio del Café. Cenicafé. Avances Técnico 402.

Puerta O., G.I; Echeverry M., J.G. (2015). Fermentación Controlada del Café: Tecnología Para Agregar Valor A La Calidad. Cenicafé. Avances Técnico 454.

Roa M., G.; Oliveros T., C.E.; Álvarez, J.; Ramírez G, C. A.; Sanz U., J.R.; Dávila, M.T.; Álvarez, J.; Zambrano, D.A.; Puerta O.., G.I.; Rodríguez, N. (1999). Beneficio Ecológico del Café. Chinchiná, Cenicafé, 1999. 300 P.

Roa M., G.; Oliveros T., C.E.; Parra C., A.; Ramírez G, C. A. (2000). El Secado Mecánico del Café. Avances Técnicos 282.

Wallis G., J.A.; Montoya R., Vélez Z., J. C.; Oliveros T., C.E. (2004). Calidad y Eficacia de Dos Métodos No Selectivos de Recolección Manual de Café (Coffea arabica). Cenicafé 55 (1): 45-51.

Workua M., Meulenaerb B., Duchateauc L., Boeckxd P. (2018). Effect of Altitude On Biochemical Composition and Quality of Green Arabica Coffee Beans Can Be Affected By Shade and Postharvest Processing Method. Food Research International. 105: 278-285.

Zambrano F, D. A. (1993). Fermente y Lave Su Café En El Tanque Tina. Cenicafé. Avance Técnico 197. 
